\title{
Evaluation of pretreatment on osmo-dried coconut properties and its impact on quinoa dessert
}

\author{
Jariyawaranugoon, U. \\ Department of Food Science and Technology, School of Science and Technology, University of the Thai \\ Chamber of Commerce, Bangkok, 10400, Thailand
}

\author{
Article history: \\ February 2018 \\ 2018

\section{Keywords:} \\ Coconut, \\ Osmo-dehydration, \\ Roselle, \\ Butterfly pea, \\ Honey, \\ Quinoa
}

Received: 2 February 2018 Received in revised form: 27

Accepted: 28 February 2018 Available Online: 8 March

\section{DOI:}

https://doi.org/10.26656/fr.2017.2(3).025

\begin{abstract}
This research was aimed to study the quality of coconut slices produced by the osmotic dehydration. Coconut slices, both unblanched and blanched samples, were treated with three pretreatment solutions such as $2 \%$ roselle, $2 \%$ butterfly pea, and $20 \%$ honey. Physicochemical and microbiological analysis of treated samples were determined against the flesh coconut (control). At the same pretreatment solution, the lower $\mathrm{pH}$, but higher acidity and moisture were found in blanched samples, and they also looked darker than unblanched samples. The blanched coconut treated with roselle and butterfly pea were superior in red and blue color, respectively. TBA values gradually increased from 0.047 to $0.546 \mathrm{mg}$ malonaldehyde $/ \mathrm{kg}$ sample after 4 weeks of storage. The blanched coconut treated with honey only showed no detectable total plate count and total yeast and mold growth throughout storage. The quinoa/coconut mixed dessert had better sensorial characteristics than the control. The dessert with butterfly pea osmo-dried coconut was the most desirable product and purchasing decision.
\end{abstract}

\section{Introduction}

Coconut (Cocos nucifera Linn.), widely grown in tropical and subtropical countries, has been increasingly consumed due to its sweet aromatic juice and palatable flesh (kernel) as well as nutritional benefits. Young coconut aged 7 - 8 months provides pleasant soft flesh favorable by all-aged consumers, and it is also rich in several minerals such as iron, phosphorus and zinc, which served for a healthier diet (Okolie et al., 2011). The coconut flesh is mostly consumed as flesh meat; besides, it is applied in many Thai desserts such as sweet sticky rice with longan and coconut cream and mung bean porridge with coconut cream. As it high moisture content $(45-50 \%)$, the coconut flesh is highly perishable, and rapidly deteriorates by chemical and microbial spoilage in a short time (Gwee, 1988). This limitation has been overcome by a technological process which transforms perishable coconut flesh into longer shelf life products. A conventional drying method is successfully applied to reduce moisture content, thereby dried coconut products can be stored for several months. Nevertheless, undesirable problems occurred such as shrinkage, harden texture and color changes, which has been reported to influence the consumer acceptance (Mujumdar, 2014), particular the elders always complain about the hard product texture.
Osmotic dehydration, a process for partially removing water from plant tissues by immersion in a hypertonic solution, has been introduced for several fruits processing. The osmotically dehydrated fruits are highly accepted by many consumers because of their fresh fruit-like attributes such as color, flavor and texture (Yadav and Singh, 2014). Besides, the pretreatment procedure such as blanching, sulfuring and honey dip has been recommended to join with the osmotic dehydration in order to maintain flavor and texture, inhibit enzymatic browning, prevent some chemical reactions such as browning oxidation, and minimize the microbial growth. Ahmad and Kumaran (2015) found the incorporation of $15 \%$ honey into aonla preserve improved its moisture and texture. The pretreatment with $0.5 \%$ sodium metabisulphite for $10 \mathrm{~min}$ before convection drying at $55^{\circ} \mathrm{C}$ for $6 \mathrm{~h}$ can enhance the lycopene content, which is a desirable quality attribute for dried tomato (OwurekuAsare et al., 2014). Chantaro et al. (2016) reported that pretreatment by blanching at $95^{\circ} \mathrm{C}$ for 5 min could improve color and consumer preference of dried osmotic dehydrated coconut. Of all pretreatments, the use of sulfur dioxide is very popular and efficient for bactericidal reduction and browning prevention. However, a reverse allergy caused by sulfur dioxide intake is being increased in a small group of the asthmatic population (Wilson and Bahna, 2005). To limit 
the dependency of sulfur dioxide, it is advisable to use natural substances instead.

Roselle calyces (Hibiscus sabdariffa Linn.) and butterfly pea (Clitoria ternatea Linn.) contain anthocyanins, flavonoids, polyphenols, organic acids, phytosterols, saponins and tannins (Ali Bradeledin et al., 2005; Mukherjee et al., 2008), which, in turn, are effective phytochemicals that have antioxidant and antimicrobial effects, and medical properties (Amro et al., 2002). Ismail et al. (2008) reported that anthocyanin and ascorbic acid are the major sources of antioxidant capacity in roselle. Also, polyphenolic compounds in roselle have been shown for the inhibitory of E. coli and fungi growth (Aziz et al., 1998). A similar result was found in the work of Tsai et al. (2002), who reported that Cilitoria ternatea showed inhibitory effects against gram positive and negative bacteria. In another purpose, both herbs have their color characteristics; red for the roselle and blue for butterfly pea, thereby the colorful finished products would be essential and feasible to enhance the consumer preference.

Quinoa (Chenopodium quinoa Willd.) is a pseudocereal cultivated in Bolivia and Peru. It is considered a superfood that contains $12-18 \%$ protein, $10-15 \%$ dietary fiber and $4-6 \%$ fat, and is a good source of minerals and vitamins, such as vitamin $\mathrm{E}$, magnesium, phosphorus and folate (Vega-Galvez et al., 2010). In comparison with cereals and legumes, quinoa has a superior content for lysine $(5-6.5 \%)$ and methionine (0.5 - 1.0\%) (Elsohaimy et al., 2015). Additionally, quinoa seeds do not contain gluten, it is a good alternative to use for celiac patients. Quinoa has been used in a variety of foods, such as biscuit, bread, and veggie burger, as well as used as a rice replacer. In the current study, the effects of various pretreatments on physicochemical and microbial properties of osmo-dried coconut slices were investigated. The best osmo-dried coconut slices were tested for their sensory acceptance as the quinoa/coconut dessert.

\section{Materials and methods}

\subsection{Coconut meat preparation}

Coconut (Cocos nucifera Linn.) in the mature stage (7 - 8 months) were procured from a local fruit market in Bangkok. The fresh coconuts, which have the firmness ranged between $21-23 \mathrm{~N}$ was selected. The shell was removed, then the coconut kernel (meat) was washed and sliced manually into $1 \mathrm{~cm}$ thick and $3 \mathrm{~cm}$ length. Dried roselle calyces and dried butterfly pea flower (Top Brand, Meridian, Co., Ltd., Thailand), honey syrup (Vejpong, Vejpong Pharmacy, Co., Ltd., Thailand) and quinoa (Arrowhead Mills, USA) were purchased from a local supermarket.

\subsection{Pretreatment process}

Three pretreatment solutions were as follows: (a) 2\% (w/v) roselle calyces, (b) $2 \%(\mathrm{w} / \mathrm{v})$ butterfly pea flower and (c) $20 \%(\mathrm{v} / \mathrm{v})$ honey. The coconut slices included unblanched and blanched samples with steam $\left(100^{\circ} \mathrm{C}\right)$ for $3 \mathrm{~min}$. The pretreatment process was performed by soaking the samples in the pretreatment solution $(1: 4, \mathrm{w} /$ v) for $10 \mathrm{~min}$, drained and dried with tissue paper. Fresh coconut slice, without the pretreatment process, was coded as control.

\subsection{Preparation of osmo-dried coconut slices}

Coconut slices were soaked in a $65^{\circ}$ Brix sucrose solution $(1: 4, \mathrm{w} / \mathrm{v})$ for $3 \mathrm{~h}$. Dehydrated coconut slices were gently washed to remove some remaining syrup and then drained. The samples were dried at $70^{\circ} \mathrm{C}$ for 3 $\mathrm{h}$, cooled, packed in polypropylene bags, and stored at ambient temperature $\left(30 \pm 2^{\circ} \mathrm{C}\right)$.

\subsection{Preparation of sweet quinoa dessert}

The control sweet quinoa dessert was formulated as follows: $100 \mathrm{~g}$ cooked quinoa, $20 \mathrm{~g}$ sugar, $15 \mathrm{~g}$ tapioca flour and $150 \mathrm{~mL}$ water. Quinoa seed was washed thoroughly and drained. The washed quinoa and water mixture $(1: 2 \mathrm{w} / \mathrm{v})$ was boiled for $20 \mathrm{~min}$ until the quinoa became soft, then let it cool at room temperature. Sweet quinoa desserts were made in 4 different formulations: the control sample (100\% quinoa) and 3 samples with $20 \%$ quinoa replacement by osmo-dried coconut slices treated with roselle calyces, butterfly pea, and honey, respectively. Sugar was added in water, mixed and heated until completely dissolved. The tapioca flour previously dissolved in a little water was added and stirred until the mixture was clear. After adding cooked quinoa, the dessert was further heated for $5 \mathrm{~min}$. A coconut cream topping was prepared by dissolved the salt $(1 \%)$ into the coconut milk, and moderately heated for 5 min with continuously stirring.

\subsection{Physicochemical analysis}

\subsection{1 pH measurement}

A $10 \mathrm{~g}$ sample was blended with $100 \mathrm{~mL}$ distilled water for $2 \mathrm{~min}$, and the $\mathrm{pH}$ was measured at ambient temperature using $\mathrm{pH}$-meter (Model 320, Mettler-Toledo Ltd., Essex, UK) (AOAC, 2000).

\subsubsection{Titratable acidity}

Total acidity was measured using the method by AOAC (2000). A $10 \mathrm{~g}$ of sample was homogenized in 50 
$\mathrm{mL}$ distilled water. The homogenate was filtered. The supernatant was titrated with $0.01 \mathrm{~N} \mathrm{NaOH}$ solution using a few drops of $1 \%$ phenolphthalein solution as an indicator. The result was calculated as a percentage of citric acid.

\subsubsection{Moisture content}

The moisture content was determined by a hot air oven method described by the AOAC (2000).

\subsubsection{Color evaluation}

A color measurement was evaluated by a Hunter Lab digital colorimeter (Model ColorFlex, Hunter Associates Laboratory, Reston, VA). Color scales recorded were lightness $\left(\mathrm{L}^{*}\right)$ value $[0$ (black) to +100 (white)], a* value $[-$ (green $),+($ red $)]$ and $b^{*}$ value $[-($ blue $),+$ (yellow) $]$.

\subsubsection{Thiobarbituric acid test (TBA)}

The rancidity was determined using the method as described by Witte et al. (1970). The colorimetric absorbance was measured at $530 \mathrm{~nm}$ using a spectrophotometer. The result was reported as the $\mathrm{mg}$ malonaldehyde $/ \mathrm{kg}$ sample.

\subsubsection{Microbiological analysis}

Sample (1, 2, 3 and 4 weeks) were subjected to microbiological analysis for total plate count (TPC) yeast and mold count (YMC) as recommended by the American Public Health Association for foodstuff examination (APHA, 2001). Total plate count was spread on plate count agar (PCA) and incubated at $37^{\circ} \mathrm{C}$ for $48 \mathrm{~h}$. For total yeast and mold count was spread on dicholan rose bengal chloramphenicol (DRBC) and the plates were incubated at $25^{\circ} \mathrm{C}$ for 5 days. Results were expressed as $\log _{10}$ colony forming unit $(\log \mathrm{CFU} / \mathrm{g})$.

\subsubsection{Sensory evaluation}

A sensory judgment was carried out by forty untrained panelists drawn from the Department of Food Science and Technology, University of the Thai Chamber of Commerce (UTCC). Samples were warmed to $40-45^{\circ} \mathrm{C}$ and served to the panelists. The panelists were asked to indicate how much they like or dislike each sample for appearance, color, taste, flavor and overall acceptability using a 9-point hedonic scale $(1=$ extremely dislike, $9=$ extremely like). The purchase intention was also assessed using a 5-point scale $(5=$ certainly would purchase, $1=$ certainly would not purchase). Panelists were instructed to cleanse their palates with distilled water before tasting the sample and anytime during the test as needed (Lawless and Heymann, 1998).

\subsubsection{Statistical analysis}

All analyses were performed in triplicate. A completely randomized design (CRD) was used for the physicochemical analysis, while a randomized complete block design (RCBD) used for the sensory evaluation. An SPSS version 10.0 software was used to perform analysis of variance (ANOVA) at $0.05 \%$ level of significance and the Duncan Multiple Range test (DMRT).

\section{Results and discussion}

\subsection{Physicochemical analysis}

Results in Table 1 show the $\mathrm{pH}$ of all osmo-dried coconut slices were in the range of $6.32-6.67$. At the same pretreatment solution, the blanched sample had lower $(\mathrm{p}<0.05) \mathrm{pH}$ values than unblanched samples, which might be due to the softened cellular structure causing higher migration of pretreatment solution (Josephine, et al., 2014). The lowest $\mathrm{pH}$ value $(\mathrm{pH}=$ 6.32) was significantly $(\mathrm{p}<0.05)$ found in the blanched coconut treated with roselle, which could be explained by the lower $\mathrm{pH}$ of roselle calyces solution $(\mathrm{pH}=3.6)$ as the presence of many organic acids including citric acid, malic acid, tartaric acid and hibiscus protocatechuic acid (Shruthi et al., 2016). The total acidity was in accordance with the $\mathrm{pH}$ value, namely the higher $\mathrm{pH}$ of blanched coconut slice showed lower total acidity in relation to that of the unblanched sample (Table 1).

Table 1. Effect of different pretreatments on physicochemical of osmo-dried coconut slices

\begin{tabular}{lccccccc}
\hline Parameter & \multicolumn{3}{c}{ Blanched } & \multicolumn{3}{c}{ Unblanched } \\
\cline { 3 - 8 } & Control & $2 \% \mathrm{RC}$ & $2 \% \mathrm{BP}$ & $20 \% \mathrm{H}$ & $2 \% \mathrm{RC}$ & $2 \% \mathrm{BP}$ & $20 \% \mathrm{H}$ \\
\hline $\mathrm{pH}$ & $6.66 \pm 0.01^{\mathrm{a}}$ & $6.32 \pm 0.03^{\mathrm{e}}$ & $6.62 \pm 0.01^{\mathrm{b}}$ & $6.57 \pm 0.01^{\mathrm{c}}$ & $6.50 \pm 0.01^{\mathrm{d}}$ & $6.66 \pm 0.02^{\mathrm{a}}$ & $6.67 \pm 0.01^{\mathrm{a}}$ \\
Titratable acidity (\%) & $0.06 \pm 0.01^{\mathrm{a}}$ & $0.08 \pm 0.02^{\mathrm{a}}$ & $0.07 \pm 0.01^{\mathrm{a}}$ & $0.06 \pm 0.02^{\mathrm{a}}$ & $0.04 \pm 0.01^{\mathrm{b}}$ & $0.03 \pm 0.02^{\mathrm{b}}$ & $0.03 \pm 0.01^{\mathrm{b}}$ \\
Moisture content (\%) & $8.33 \pm 0.11^{\mathrm{a}}$ & $7.26 \pm 0.37^{\mathrm{b}}$ & $8.87 \pm 0.13^{\mathrm{a}}$ & $7.48 \pm 0.68^{\mathrm{b}}$ & $6.98 \pm 0.43^{\mathrm{b}}$ & $8.64 \pm 0.72^{\mathrm{a}}$ & $7.32 \pm 0.41^{\mathrm{b}}$ \\
$L^{*}$ value & $81.31 \pm 0.01^{\mathrm{a}}$ & $74.73 \pm 0.03^{\mathrm{e}}$ & $66.32 \pm 0.02^{\mathrm{f}}$ & $81.11 \pm 0.05^{\mathrm{b}}$ & $77.21 \pm 0.08^{\mathrm{c}}$ & $76.36 \pm 0.04^{\mathrm{d}}$ & $81.16 \pm 0.02^{\mathrm{b}}$ \\
$a^{*}$ value & $-0.57 \pm 0.03^{\mathrm{c}}$ & $0.65 \pm 0.01^{\mathrm{a}}$ & $-7.29 \pm 0.01^{\mathrm{g}}$ & $-0.95 \pm 0.04^{\mathrm{d}}$ & $-0.23 \pm 0.03^{\mathrm{b}}$ & $-1.25 \pm 0.03^{\mathrm{e}}$ & $-1.67 \pm 0.04^{\mathrm{f}}$ \\
$b^{*}$ value & $8.35 \pm 0.03^{\mathrm{b}}$ & $5.40 \pm 0.02^{\mathrm{e}}$ & $-9.73 \pm 0.05^{\mathrm{g}}$ & $7.69 \pm 0.08^{\mathrm{c}}$ & $7.05 \pm 0.06^{\mathrm{d}}$ & $0.15 \pm 0.08^{\mathrm{f}}$ & $8.64 \pm 0.08^{\mathrm{a}}$ \\
\hline
\end{tabular}

${ }^{a-e}$ Different superscript letters in the same row indicate significant difference $(\mathrm{p}<0.05)$. Control $=$ fresh coconut slices, and $\mathrm{RC}, \mathrm{BP}$, and $\mathrm{H}=$ coconut slices treated with $2 \%$ roselle, $2 \%$ butterfly pea, and $20 \%$ honey, respectively 
The moisture content of all osmo-dried coconut slices ranged between $6.98-8.87 \%$ (Table 1). This indicated the longer storage stability of the coconut slices, which was confirmed by the work of Abano et al. (2013) who reported that the dried fruits having $20 \%$ moisture or below could be less in microbial growth and enzyme activity.

The color results of osmo-dried coconut slices in Table 1 showed $(\mathrm{p}<0.05)$ the highest $L^{*}$ value in the control, while those of treated samples were varied by the kind of pretreatment solution. The blanched coconut treated with roselle and butterfly pea showed superior in red and blue color, respectively, possibly due to their natural anthocyanin pigments such as roselle calyces (pelargonidin) and butterfly pea flower (cyanidin) (Ismail et al., 2008; Zingare et al., 2013).

\subsection{Storage stability of osmo-dried coconut slices}

\subsubsection{TBA value}

Changes in TBA value during storage of osmo-dried coconut slices are indicated in Table 2 . TBA values in all samples gradually increased from 0.047 to $0.546 \mathrm{mg}$ malonaldehyde $/ \mathrm{kg}$ sample after 4 weeks of storage. Ke et al. (1984) indicated that TBA value which below 0.576 $\mathrm{mg}$ malonaldehyde $/ \mathrm{kg}$ sample showed no rancidity, whereas that for $0.65-1.44 \mathrm{mg}$ malonaldehyde $/ \mathrm{kg}$ sample regarded as rancid but still acceptable. Hence, the TBA values recorded in all coconut samples were still below the oxidative rancidity level. With comparison to the control, lower TBA values were observed in treated samples, which might be due to both roselle calyces and butterfly pea flower contain natural antioxidant substances; for example, anthocyanin like delphinidin-3glucosides, sambubiosides, and cyaniding-3sambubiosides as well as flavonoids including flavonols, flavones, and flavonones (Jung et al., 2013). While, honey is composed of flavonoids (chrysin, pinocembrin, pinobanksin, quercetin, kaempferol), phenolic acids (cafferic, coumaric, ferrulic, ellagic), and ascorbic acid, which have effective antioxidant activity as well (Taormina et al., 2001).

\subsubsection{Microbiological analysis}

There was no microbial growth in all samples after 2 weeks of storage (Table 2). After 3 weeks of storage, the microbial counts found in the control and treated sample with roselle were 5.4 and $4.4 \log \mathrm{CFU} / \mathrm{g}$, respectively, which were higher than the spoilage limit of fruit product (4 $\log \mathrm{CFU} / \mathrm{g}$ ) (Thailand Industrial Standards Institute, 1989). The microbial counts were not found in both butterfly pea and honey coconut slices throughout the storage period. The use of honey only showed no detectable total yeast and mold growth in samples throughout 4 weeks of storage. This might be due to honey contains higher antimicrobial compounds such as hydrogen peroxide, lysozyme, phenolic acid, and flavonoids (Taormina et al., 2001). This was in agreement with Ergun and Ergun (2009) who found that total microbial count for untreated arils was $6.90 \mathrm{log}$ $\mathrm{CFU} / \mathrm{g}$ while for arils treated with the 10 and $20 \%$ diluted honey solution reached only 4.40 and $4.45 \mathrm{log}$ $\mathrm{CFU} / \mathrm{g}$, respectively after 10 days of chilled storage. Microbial counts were highly lowered in the blanched coconut, possibly because of the enzyme inactivation and microorganism reduction caused by the heat treatment, as confirmed by Brennand (1994).

\subsubsection{Sensory evaluation of sweet quinoa dessert}

Sensory data of sweet quinoa desserts containing various types of osmo-dried coconut are presented in Table 3. The dessert with osmo-dried coconut treated with butterfly pea significantly showed $(\mathrm{p}<0.05)$ higher sensorial improvement than that with roselle, and both samples were well accepted than the control dessert (100\% quinoa). Although incorporation of honey treated coconut seemed to improve sensorial characteristics of quinoa dessert, no significant differences $(p>0.05)$ were found in relation to the control. The presence of roselle and butterfly pea coconut slices significantly increased sensory attributes of the quinoa desserts, which might be due to the sweet taste, palatable texture, and colorful appearance of the coconut slices. This was reflected by the development of appearance, texture, and taste of the control dessert, which correspond to the term "indifferent" and "dislike slightly" became "like slightly" and "like moderately" in quinoa/coconut mixed desserts. When considering the overall acceptability, the dessert with butterfly pea coconut was the most desirable product $(\mathrm{p}<0.05)$, while others with roselle and honey coconut were comparable to the control $(p>0.05)$. Additionally, when classified the overall acceptability scores into three sensorial groups, such as (1) 'dislike' (score 1-3), (2) 'indifferent' (score 4-6), and (3) 'like' (score 7 - 9), as shown in Figure 1a-d. It was observed that the percentages of panelists who were disliked, indifferent, and liked the control dessert were 10, 50, and 40\%, respectively (Figure 1a). When incorporating with $20 \%$ osmo-dried coconuts, the percentages of panelists giving these liking scores (score $7-9$ ) to quinoa dessert with roselle, butterfly pea, and honey osmo-dried coconut were increased from the control (40\% liking category) to be $50-90 \%$ (Figure $1 \mathrm{~b}$ $-\mathrm{d}$ ). This revealed, when classified the scores rated for overall acceptability into three categories as abovementioned, an additional sensory information showing that the panelists preferred and not reluctant to accept the 
Table 2. Effect of different pretreatments on TBA values and microbiological analysis of osmo-dried coconut slices during storage.

\begin{tabular}{|c|c|c|c|c|c|}
\hline \multirow[t]{2}{*}{ Treatment } & \multicolumn{5}{|c|}{ Storage time (weeks) } \\
\hline & & 1 & 2 & 3 & 4 \\
\hline \multicolumn{6}{|c|}{ TBA (mg malonaldehyde/kg sample) } \\
\hline Control & & $0.140 \pm 0.02^{\mathrm{CA}}$ & $0.234 \pm 0.01^{\mathrm{bA}}$ & $0.265 \pm 0.01^{\mathrm{bB}}$ & $0.546 \pm 0.01^{\mathrm{aA}}$ \\
\hline \multirow[t]{3}{*}{ Blanched } & Roselle & $0.060 \pm 0.02^{c B}$ & $0.218 \pm 0.01^{\mathrm{bB}}$ & $0.234 \pm 0.03^{\mathrm{bC}}$ & $0.460 \pm 0.06^{\mathrm{aB}}$ \\
\hline & Butterfly pea & $0.070 \pm 0.02^{c B}$ & $0.195 \pm 0.01^{\mathrm{bC}}$ & $0.211 \pm 0.02^{\mathrm{bC}}$ & $0.437 \pm 0.01^{\mathrm{aB}}$ \\
\hline & Honey & $0.062 \pm 0.01^{\mathrm{CB}}$ & $0.187 \pm 0.01^{\mathrm{bC}}$ & $0.179 \pm 0.01^{\mathrm{bD}}$ & $0.452 \pm 0.02^{\mathrm{aB}}$ \\
\hline \multirow{3}{*}{ Unblanched } & Roselle & $0.047 \pm 0.01^{\mathrm{cC}}$ & $0.211 \pm 0.03^{\mathrm{bB}}$ & $0.242 \pm 0.02^{\mathrm{bC}}$ & $0.343 \pm 0.05^{a C}$ \\
\hline & Butterfly pea & $0.060 \pm 0.02^{\mathrm{dB}}$ & $0.226 \pm 0.01^{\mathrm{CB}}$ & $0.318 \pm 0.01^{\mathrm{bA}}$ & $0.452 \pm 0.02^{\mathrm{aB}}$ \\
\hline & Honey & $0.094 \pm 0.02^{\mathrm{CA}}$ & $0.203 \pm 0.02^{\mathrm{bB}}$ & $0.203 \pm 0.01^{\mathrm{bc}}$ & $0.445 \pm 0.01^{\mathrm{aB}}$ \\
\hline \multicolumn{6}{|c|}{ Total plate count (log CFU/g) } \\
\hline Control & & ND & ND & 5.4 & 6.8 \\
\hline \multirow[t]{3}{*}{ Blanched } & Roselle & ND & ND & ND & 4.0 \\
\hline & Butterfly pea & ND & ND & ND & ND \\
\hline & Honey & ND & ND & ND & ND \\
\hline \multirow[t]{3}{*}{ Unblanched } & Roselle & ND & ND & 4.4 & 6.1 \\
\hline & Butterfly pea & ND & ND & ND & 6.2 \\
\hline & Honey & ND & ND & ND & 3.5 \\
\hline \multicolumn{6}{|c|}{ Yeast and mold (log CFU/g) } \\
\hline Control & & ND & ND & ND & 5.7 \\
\hline \multirow[t]{3}{*}{ Blanched } & Roselle & ND & ND & ND & 4.0 \\
\hline & Butterfly pea & ND & ND & ND & 3.9 \\
\hline & Honey & ND & ND & ND & ND \\
\hline \multirow[t]{3}{*}{ Unblanched } & Roselle & ND & ND & ND & 5.0 \\
\hline & Butterfly pea & ND & ND & ND & 4.1 \\
\hline & Honey & ND & ND & ND & 4.0 \\
\hline
\end{tabular}

${ }^{a-d}$ Different superscript letters in the row indicate significant differences $(p<0.05)$ among different storage times for the same sample

${ }^{A-C}$ Different superscript letters in the column indicate significant differences $(\mathrm{p}<0.05)$ among different samples at the same storage time

$\mathrm{ND}=$ not detected

(a)

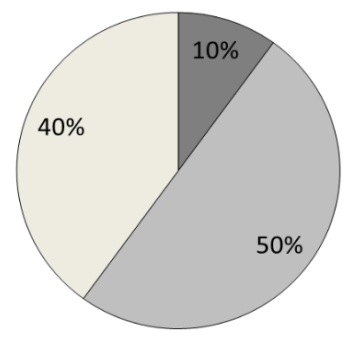

Control

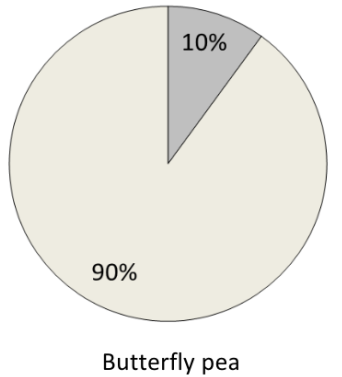

(b)

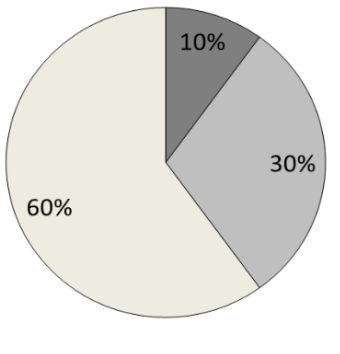

Roselle

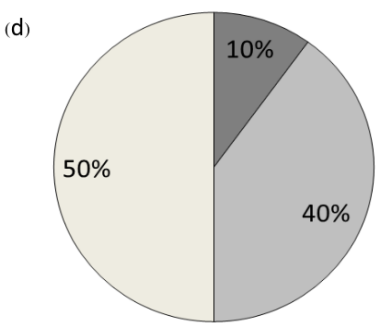

Honey

score 1 - 3 (dislike) $\square$ score 4 - 6 (indifferent)

$\square$ score 7 - 9 (like)

Figure 1. Percentage distribution for scores of overall acceptability of quinoa/coconut mixed desserts: (a) control, (b) roselle, (c) butterfly pea, and (d) honey.

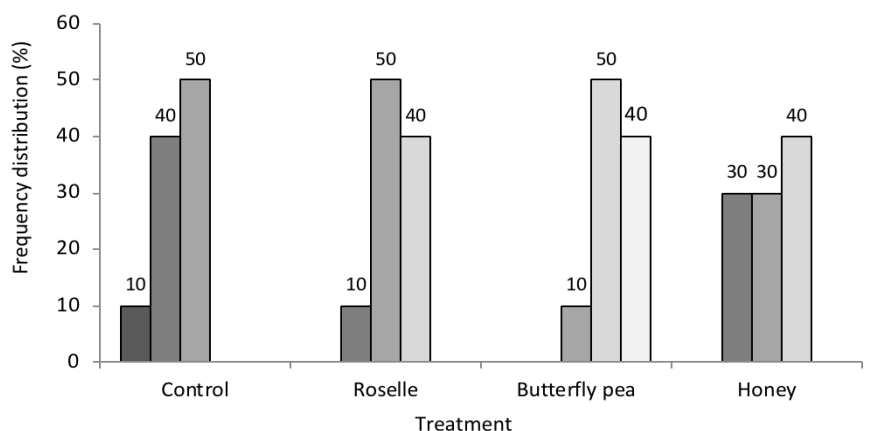

score $1 \square$ score $2 \square$ score $3 \square$ score $4 \square$ score 5

Figure 2. Percentage purchasing intention for quinoa/ coconut mixed desserts. Based on a 5 -point scale $(5=$ certainly would purchase, $1=$ certainly would not purchase)

Table 3. Sensory attributes and purchase intention of sweet quinoa dessert

\begin{tabular}{lrrrr}
\hline Attributes & Control & \multicolumn{3}{c}{ Quinoa: osmo-dried coconut ratio $(80: 20)$} \\
\cline { 3 - 5 } & $(100 \%$ quinoa $)$ & Roselle & Butterfly pea & Honey \\
\hline Appearance & $5.67 \pm 0.97^{\mathrm{b}}$ & $6.53 \pm 0.51^{\mathrm{a}}$ & $6.93 \pm 1.27^{\mathrm{a}}$ & $6.13 \pm 1.24^{\mathrm{ab}}$ \\
Flavor & $6.33 \pm 0.48^{\mathrm{b}}$ & $6.53 \pm 0.63^{\mathrm{b}}$ & $7.13 \pm 1.12^{\mathrm{a}}$ & $6.46 \pm 0.83^{\mathrm{b}}$ \\
Texture & $4.87 \pm 1.02^{\mathrm{c}}$ & $6.13 \pm 1.23^{\mathrm{b}}$ & $7.07 \pm 1.23^{\mathrm{a}}$ & $5.33 \pm 1.11^{\mathrm{c}}$ \\
Taste & $4.87 \pm 1.20^{\mathrm{c}}$ & $6.00 \pm 1.25^{\mathrm{b}}$ & $7.47 \pm 1.18^{\mathrm{a}}$ & $5.60 \pm 1.06^{\mathrm{bc}}$ \\
Overall acceptability & $5.53 \pm 1.04^{\mathrm{b}}$ & $6.27 \pm 1.08^{\mathrm{b}}$ & $7.60 \pm 1.10^{\mathrm{a}}$ & $5.87 \pm 1.26^{\mathrm{b}}$ \\
\hline Purchase intention & $2.47 \pm 0.63^{\mathrm{c}}$ & $3.33 \pm 0.72^{\mathrm{b}}$ & $4.27 \pm 0.70^{\mathrm{a}}$ & $3.07 \pm 0.88^{\mathrm{b}}$ \\
\hline
\end{tabular}

${ }^{a-c}$ Different superscripts letters in the same row indicate significant difference $(\mathrm{p}<0.05)$ 
product, reflected by the absence of 'indifferent' panelists. Evidently, $90 \%$ of panelists were satisfactory with the dessert with butterfly pea coconut, and all rated for the scores between 7 to 9 . It was corresponded to the highest overall acceptance in Table 3, while the lower acceptance found in the desserts with roselle and honey coconuts. Thus, one can infer that the addition of osmodried coconuts could improve the sensorial characteristics of sweet quinoa desserts. Besides, the colorful appearance is an important psychological factor which stimulates the consumer behavior and visual perception.

The results of purchasing decision illustrated in Figure 2 show the highest (90\%) distribution in both scores of 5 and 4 (would certainly and possibly buy the product) found in the quinoa dessert with butterfly pea coconut. No panelists rated with a score of 5 for the desserts with roselle and honey coconut. The least acceptable product was the control which found approximately $50 \%$ of panelists presenting their no purchasing intention. The finding implied that, though the quinoa desserts with osmo-dried coconuts have better characteristics, most panelists prefer the colorful of the dessert which supports in their purchase.

\section{Conclusion}

The osmo-dried coconut slice is a possible alternative to fresh coconut processing. The blanching process followed by the pretreated solution could be used to improve the quality and shelf life of osmo-dried coconut. The pretreatment with $20 \%$ honey solution was the most effective to extend the shelf life of osmo-dried coconut slices, while that with $2 \%$ butterfly pea solution improved color, taste and texture of coconut slices, which positively promoted the sensorial characteristics of quinoa dessert. The quinoa/butterfly pea coconut (80:20) mixed dessert was characterized by the most preferred quality as well as colorful appearance in contrast to the control (100\% quinoa). Further research to develop a low-caloric quinoa dessert should be investigated.

\section{Acknowledgement}

The author would like to thank the University of the Thai Chamber of Commerce for providing the necessary laboratory facilities.

\section{References}

Abano, E.E., Sam-Amoah, L.K., Owusu, J. and Engmann, F.N. (2013). Effect of ascorbic acid, salt, lemon juice, and honey on drying kinetics and sensory characteristics of dried mango. Croatian Journal of Food Science and Technology, 5(1), 1-10.

Ahmad, S. and Kumaran, N. (2015). Studies in the effects of honey incorporation on quality and shelf life of aonla preserve. Cogent Food and Agriculture, 1, 1-8. https:// doi.org/10.1080/23311932.2015.1009334

Ali-Bradeldin, H., Al-Wabel, N. and Gerald, B. (2005). Phytochemical pharmacological and toxicological aspects of Hibiscus sabdariffa: a review. Phytotherapy Research, 19, 369-375. https:// doi.org/10.1002/ptr.1628

Amro, B., Aburjai, T. and Al-Khalil, S. (2002). Antioxidative and radical scavenging effects of olive cake extract. Fitoterapia, 73(6), 456-461. https:// doi.org/10.1016/S0367-326X(02)00173-9

AOAC. (2000). Association of Official Analytical Chemists. Official methods of analysis. $15^{\text {th }}$ ed. Arlington: Association of Official Analytical Chemists.

APHA. (2001). Compendium of Method for the Microbiological Examination of Foods. $4^{\text {th }}$ ed. Washington, DC: American Public Health Association.

Aziz, H.N., Farag, S.E. and Mousa, L.A. (1998). Comparative antibacterial and antifungal effects of some phenolic compounds. Microbios, 93(374), 4354.

Brennand, C.P. (1994). Home Drying of Food. Utah: The Utah State University Cooperative ExtensionOffice, Utah State University.

Chantaro, P., Sribuathong, S., Charoen, R. and Chalermchaiwat, P. (2016). Pre-treatment conditions effect quality and sensory acceptability of dried osmotic dehydrated coconut. International Food Research Journal, 23(4), 1453-1458.

Elsohaimy, S.A., Refaay, T.M. and Zaytoun, M.A.M. (2015). Physicochemical and functional properties of quinoa protein isolate. Annals of Agricultural Sciences, 60, 297-305. https://doi.org/10.1016/ j.aoas.2015.10.007

Ergun, M. and Ergun, N. (2009). Maintaining quality of minimally processed pomegranate arils by honey treatments. British Food Journal, 111(4), 396-406. https://doi.org/10.1108/00070700910951524

Gwee, C.N. (1988). New Technologies Open the Passage into New Usage of Coconut Milk Products.In Maneepun, S., Varangoon, P. and Phithakpol, B. (Eds). Food Science and Technology in Industrial Development, p. 157-162. Bangkok: Institute of 
Food Research and Product Development, Kasetsart University.

Ismail, A., Ikram, E.H.K. and Nazri, H.S.M. (2008). Roselle (Hibiscus sabdariffa L.) seeds-nutritional composition, protein quality and health benefits. Food, 2(1), 1-16.

Josephine, S.N., Baskar, G. and Singh, A. (2014). Effect of various pretreatment methods on osmotic dehydration of fruits for qualitative and quantitative advantage. International Journal of ChemTech Research, 6(12), 4995-5001.

Jung, E., Kim, Y. and Joo, N. (2013). Physicochemical properties and antimicrobial activity of Roselle (Hibiscus sabdariffa L.). Journal of the Science of Food and Agriculture, 93(15), 3769-3776. https:// doi.org/10.1002/jsfa.6256

Ke, P.J., Cervants, E. and Robles-Martinez, C. (1984). Determination of Thiobarbituric acid reactive substances (TBARS) in fish tissue by an improved distillation spectrophotometric method. Journal of Science and Food Agricultural, 35, 1248-1254. https://doi.org/10.1002/jsfa.2740351117

Lawless, H.T. and Heymann, H. (1998). Sensory Evaluation of Food: Principles and Practices. New York: Chapman and Hall.

Mujumdar, A.S. (2014). Handbook of Industrial Drying. $4^{\text {th }}$ ed. London: CRC Press.

Mukherjee, P.K., Kumar, V., Kumar, N.S. and Heinrich, M. (2008). The Ayurvedic medicine Clitoria ternatea from traditional use to scientific assessment. Journal of Ethnopharmacology, 120, 291-301. https://doi.org/10.1016/j.jep.2008.09.009

Okolie, P.N., Obi, C.L. and Uaboi-Egbenni, P.O. (2011). Fungal spoilage of Coconut (Cocos nucifera L.) fruits during storage and the growth differential of isolates on selected amino acids and carbohydrates. Pakistan Journal of Nutrition, 10(10), 965-973. https://doi.org/10.3923/pjn.2011.965.973

Owureku-Asare, M., Agyei-Amponsah, J., Saalia, F. and Alfaro, L. (2014). Effect of pretreatment on physicochemical quality characteristics of a dried tomato (Lycopersicon esculentum). African Journal of Food Science, 8(5), 253-259. https:// doi.org/10.5897/AJFS2014.1156

Shruthi, V.H., Ramachanda, C.T., Nidoni, U., Hiregoudar, S., Naik, N. and Kurubar, A.R. (2016). Roselle (Hibiscus sabdariffa L.) as a source of natural colour: a review. Plant Archives, 16(2), 515522.

Taormina, P.J., Niemira, B.A. and Beuchat, L.R. (2001). Inhibitory activity of honey against foodborne pathogens as influenced by the presence of hydrogen peroxide and level of antioxidant power. International Journal of Food Microbiology, 69(3), 217-225. https://doi.org/10.1016/S0168-1605(01) 00505-0

Thailand Industrial Standards Institute (TIS). (1989). Industry Standard Dried Fruit (TIS-919-1989). Retrieved on January 5, 2018 from TIS Website: http:///www.tisi.go.th.

Tsai, P.J., Mc-Intosh, J., Pearec, P., Camden, B. and Jordan, B.R. (2002). Anthocyanin and antioxidant capacity in Roselle (Hibiscus sabdariffa L.) extract. Food Research International, 35(4), 351-356. https://doi.org/10.1016/S0963-9969(01)00129-6

Vega-Galez, A., Miranda, M., Vergara, J. and Uribe, E., Puente, L. and Martinez, E.A. (2010). Nutrition facts and functional potential of quinoa (Chenopodium quinoa Wild,) an ancient Andean grain: a review. Journal of the Science of Food and Agriculture, 90 (15), 2541-2547. https://doi.org/10.1002/jsfa.4158

Wilson, B.G. and Bahna, S.L. (2005). Adverse reactions to food additives. Annals of Allergy Asthma and Immunology, 95(6), 499-507. https:// doi.org/10.1016/S1081-1206(10)61010-1

Witte, V.C., Krause, G.F. and Bailey, M.E. (1970). A new extraction method for determining 2thiobarbituric acid values of pork and beef during storage. Journal of Food Science, 35(5), 582-585. https://doi.org/10.1111/j.1365-2621.1970.tb04815.x

Yadav, A.K. and Singh, S.V. (2014). Osmotic dehydration of fruits and vegetables: a review. Journal Food Science and Technology, 51(9), 16541673. https://doi.org/10.1007/s13197-012-0659-2

Zingare, M.L., Zingare, P.L., Dubey, A.K. and Ansari, A. (2013). Clitoria ternatea (Aparajita): a review of the antioxidant, antidiabetic and hepatoprotective potentials. International Journal of Pharmacy and Biological Sciences, 3(1), 203-213. 